\title{
THE INFLUENCE OF 18Cr10NiTi AND ODS 18Cr10NiTi AUSTENITIC STAINLESS STEELS MICROSTRUCTURE ON THE DEUTERIUM DESORPTION
}

\author{
A.S. Kalchenko ${ }^{1}$, V.V. Ruzhytskyi ${ }^{1}$, S.A. Karpov ${ }^{1}$, I.V. Kolodiy ${ }^{1}$, M.A. Tikhonovsky, \\ G.D. Tolstolutskaya ${ }^{1}$, A.N. Velikodnyi ${ }^{1}$, and V.N. Voyevodin ${ }^{1,2}$ \\ ${ }^{1}$ National Science Center “Kharkov Institute of Physics and Technology”, Kharkiv, Ukraine; \\ ${ }^{2}$ V.N. Karazin Kharkiv National University, Kharkiv, Ukraine \\ E-mail: kalchenko@kipt.kharkov.ua
}

The thermal desorption spectra of deuterium from 18Cr10NiTi and ODS 18Cr10NiTi steel specimens irradiated with $10 \mathrm{keV} \mathrm{D}{ }_{2}^{+}$ions were examined. The influence of radiation damage on microstructure and accumulation of deuterium implanted in steels at room temperature and after annealing have been studied. Thermal desorption spectrum (TDS) from a specimen of ODS 18Cr10NiTi steel exhibits deuterium release over a wide temperature range with two well-defined maxima at $\sim 420$ and $\sim 970 \mathrm{~K}$. Two types of precipitates - oxides (Y-Ti-O) and carbides $\mathrm{TiC}$ are considered to explain the mechanism of the deuterium trapping to high annealing temperatures.

\section{INTRODUCTION}

The interaction of hydrogen with defects in solids has a profound effect on the mechanical properties of materials. The characterization of trapping and release behavior of hydrogen and its isotopes is one of the key issues for the development of materials for innovative nuclear systems. Thermal desorption spectrometry has been proved to be an effective experimental method to provide access to study the kinetic of diffusion and trapping behaviors of $\mathrm{H}$ (D) in metals.

Materials with high irradiation resistance that can operate at high temperature and stresses are needed for advanced nuclear reactors. Ni based super alloys and austenitic steels were considered to be excellent choice of material due to their closely packed structure. Austenitic stainless steels have high creep resistance but their void swelling resistance is lower when compared with ferritic steels. The creep and void swelling resistance in austenitic stainless steel can be improved by dispersing ultra-fine stable oxide particles. These oxide particles are expected to reduce grain coarsening and grain boundary sliding and thereby increase the creep resistance. The interface between these oxides and matrix can act as a sink for voids and increases the void swelling resistance in austenitic steels. For developing structural materials of fusion reactors and core components of advanced fission reactors, ODS austenitic stainless steels could be an attractive material because of their corrosion resistance, high-temperature strength and irradiation properties [1].

Recent work suggested that the oxide particles in the ODS steels were effective trapping site for helium, hydrogen and vacancies, so that the oxide particles have an influence on the nucleation and growth of cavities [2]. It is known that hydrogen gas can be stored in irradiated austenitic steels at concentrations significantly in excess of those predicted by Sieverts' law [3]. The retention and accumulation of hydrogen in irradiated materials are most likely caused by the presence of high concentrations of microstructural trapping sites. Despite a great number of theoretical and experimental studies, the capture mechanisms and the nature of hydrogen traps still remain unclear.
In our papers we showed that irradiation of $18 \mathrm{Cr} 10 \mathrm{NiTi}$ stainless steel to the damage level of $\sim 50$ displacements per atom (dpa) or pre-implantation with helium causes the formation of traps that can retain hydrogen in the temperature range from 500 to $1000 \mathrm{~K}$ and increase the amount of retained deuterium by an order of magnitude in the $350 \ldots 550 \mathrm{~K}$ region [4, 5]. However, the data on austenitic ODS steels is limited.

In the current study we investigate the influence of initial microstructure and radiation damages on the desorption and trapping of deuterium implanted in 18Cr10NiTi and ODS 18Cr10NiTi steels.

\section{MATERIAL AND METHODS}

The specimens used were foils of $18 \mathrm{Cr} 10 \mathrm{NiTi}$ austenitic stainless steel and its strengthened version measuring $7 \times 7 \times 0.1 \mathrm{~mm}$. The structural features of $18 \mathrm{Cr} 10 \mathrm{NiTi}$ steel mechanically alloyed with $80 \% \mathrm{Y}_{2} \mathrm{O}_{3}-$ $20 \% \mathrm{ZrO}_{2}$ nanosized oxide (in molar percent) were investigated in [6]. Thin foils were obtained by mechanical thinning of the disks down to $200 \mu \mathrm{m}$ followed by electropolishing. After electropolishing, just prior to irradiation in the experimental chamber, the specimens were short-term annealed at $1320 \mathrm{~K}$ for surface cleaning and degassing. The temperature of implantation and annealing was monitored using a chromel-alumel thermocouple welded to the specimen.

The steels were irradiated with a beam of deuterium ions. The substitution of deuterium for hydrogen has allowed us to separate the ion-implanted hydrogen released out of the samples from hydrogen released out of experimental chamber components at heating. It is known that the mass difference of deuterium and hydrogen can influence the determination of the thermal-dynamic parameters (via the well-known isotope effect). However, no differences were observed in thermal desorption spectra upon change of deuterium to hydrogen [7]. Hydrogen (deuterium) was implanted to doses $0.01 \ldots 1 \cdot 10^{17} \mathrm{~cm}^{-2}$ with an energy of $5 \mathrm{keV} / \mathrm{D}$ at room temperature.

The SRIM code [8] was used to evaluate the ion projected ranges $(R \mathrm{p})$ and range straggling $(\Delta R \mathrm{p})$, the concentration of gas atoms, and the dpa. The calculations were performed with a target density of 
$7.9 \mathrm{~g} \cdot \mathrm{cm}^{-3}$ and a displacement threshold energy of $40 \mathrm{eV}$.

The deuterium release from steels was investigated by the thermal desorption technique in the temperature range from 300 to $1400 \mathrm{~K}$ at a rate of $6 \mathrm{~K} \cdot \mathrm{s}^{-1}$. The gas release was registered by a monopole massspectrometer. Irradiations and measurements of TDS were performed in one chamber, to exclude contact of the specimens with air that prevented the formation of artifact trap sites associated with the surface oxide [9]. The residual gas pressure in the experimental chamber was measured to be $\sim 5 \cdot 10^{-5} \mathrm{~Pa}$.

Microstructural and swelling data were extracted using conventional techniques conducted on JEM100CX and JEM-2100 transmission electron microscopes, employing standard bright-field techniques. The JEM-2100 is equipped with a Gatan imaging filter (GIF) for energy filtered transmission electron microscopy (EFTEM) image acquisition. Analysis of TEM micrographs were performed using image processing software. The TEM sample thickness was determined using a convergent beam electron diffraction (CBED) pattern acquired in the two-beam approximation [10]. The thickness estimation method is
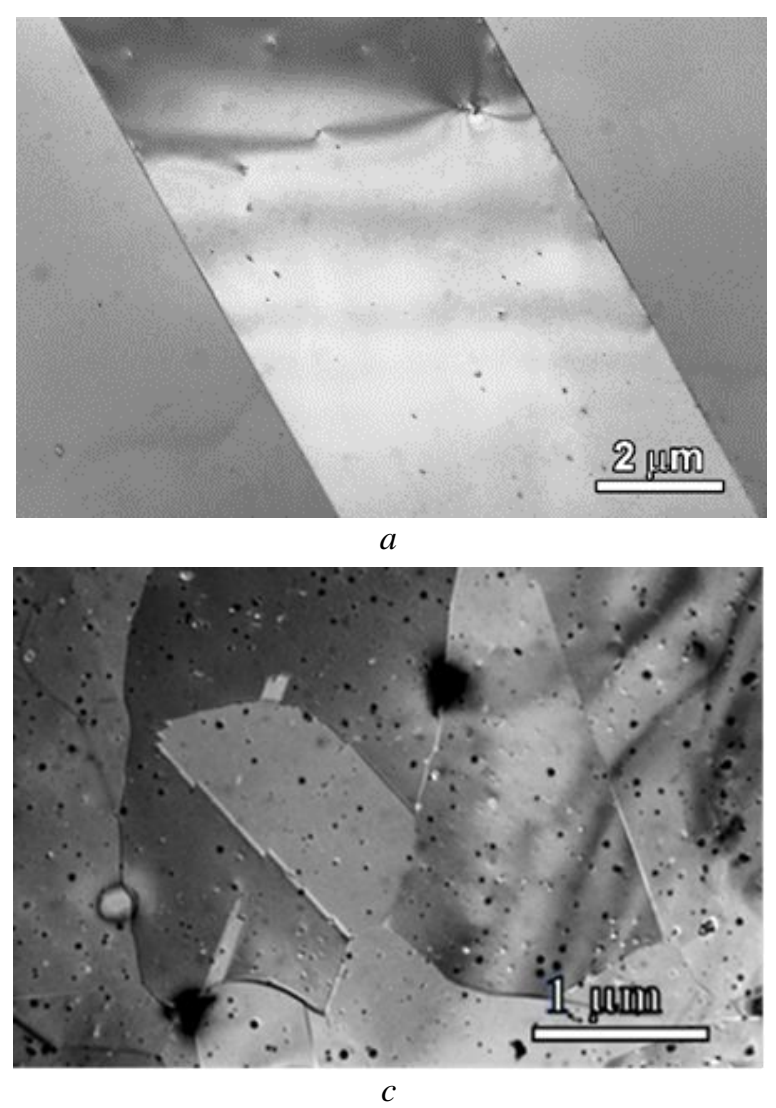

based on a comparison of the measured and simulated intensity profiles across the diffraction disc.

\section{RESULTS AND DISCUSSION}

The initial pre-irradiation structure of $18 \mathrm{Cr} 10 \mathrm{NiTi}$ steel is shown in Fig. 1,a. After solution annealing microstructure contains twins of annealing precipitates of second phase (and titanium carbonitrides) and dislocations (see Fig. 1,b). Majority of perfect $s$ are extended on partial dislocations with stacking fault formation. Sum density of dislocations is $\sim 10^{8} \mathrm{~cm}^{-2}$. Average grain size was $\sim 30 \mu \mathrm{m}$.

Grain structure of ODS steel was approximately the same for all samples. The average grain size was 1.2..2.0 $\mu \mathrm{m}$ (see Fig. 1,c). Near-uniform distribution of precipitates with a size of $\sim 10 \mathrm{~nm}$ and a volume density of $1 \cdot 10^{22} \mathrm{~m}^{-3}$ are observed for all samples.

The precipitates predominantly have the crystal lattice and from the results of EDS analyses, it was found that most of particles were mainly complex oxides (Y ( $\mathrm{Zr}$ )-Ti-O) (see Fig. 1,d). In addition, it was observed precipitates $\mathrm{TiC}$ as specific in $18 \mathrm{Cr} 10 \mathrm{NiTi}$ steel and a certain amount in ODS $18 \mathrm{Cr} 10 \mathrm{NiTi}$ steel. The high magnification observation revealed that some particles show moiré fringes (see insert Fig. 1,d).
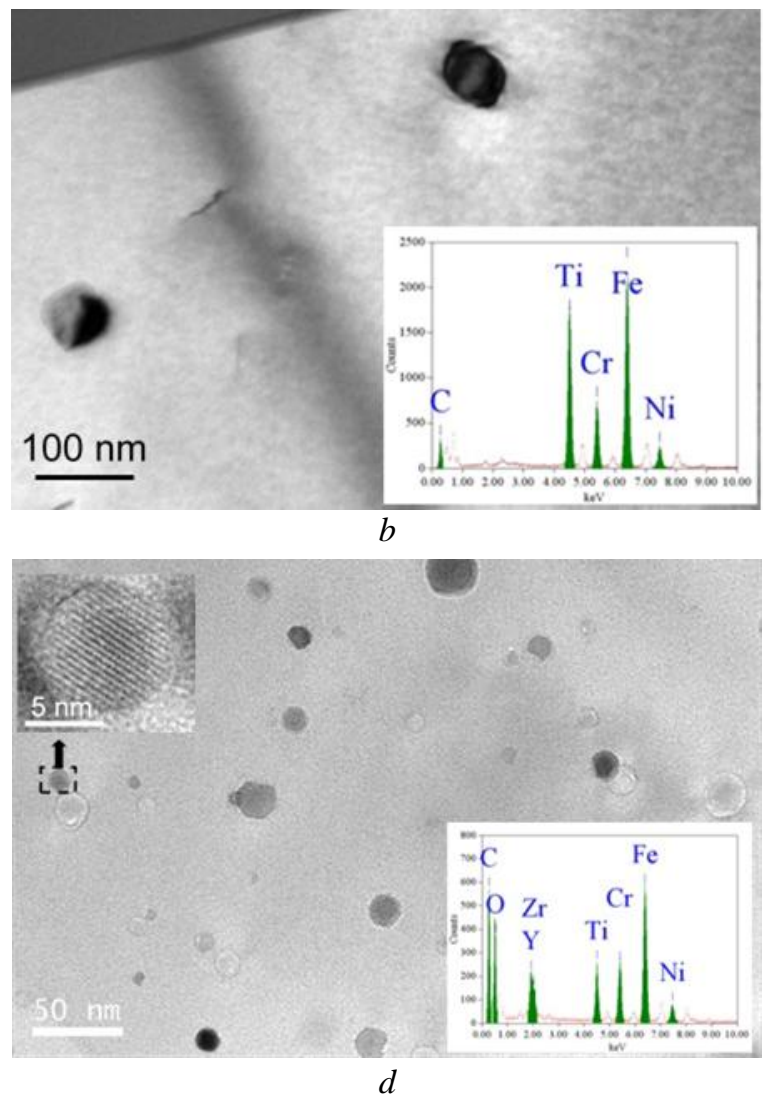
electron microprobe analysis of precipitates (inset $b, d)$

Fig. 2 shows the thermal desorption spectra of deuterium from 18Cr10NiTi and ODS 18Cr10NiTi steel specimens irradiated with $10 \mathrm{keV} \mathrm{D}_{2}{ }^{+}$ions. The typical thermal desorption spectrum of deuterium from $18 \mathrm{Cr} 10 \mathrm{NiTi}$ irradiated at $290 \mathrm{~K}$ to $10^{15} \ldots 10^{17} \mathrm{D}_{2}{ }^{+} / \mathrm{cm}^{2}$ has natively simple structure. One major peak with two weakly resolved maxima at temperatures 380 and $430 \mathrm{~K}$ is observed. In our previous investigations it is shown that with dose increasing from $1 \cdot 10^{14} \ldots 1 \cdot 10^{16} \mathrm{~cm}^{-2}$ the amplitude of the deuterium peak increases and the temperature range of gas release shifts to higher temperatures [11].

The amount of released deuterium for all implantation doses (corrected for a reflection factor of 
$\sim 0.1$ [12]) for $5 \mathrm{keV} \mathrm{D}^{+}$ions is $\sim 90 \%$ of the implanted dose. Desorption is completing by $600 \mathrm{~K}$.

The thermal desorption spectrum from a specimen of ODS 18Cr10NiTi steel, where deuterium was implanted at $300 \mathrm{~K}$ to $(0.01 \ldots 1.0) \cdot 10^{17} \mathrm{D}_{2}^{+} / \mathrm{cm}^{2}$ exhibits deuterium release over a wide temperature range with two welldefined maxima at $\sim 420$ and $\sim 970 \mathrm{~K}$ (see Fig. 2,b). In first temperature region, the character of deuterium

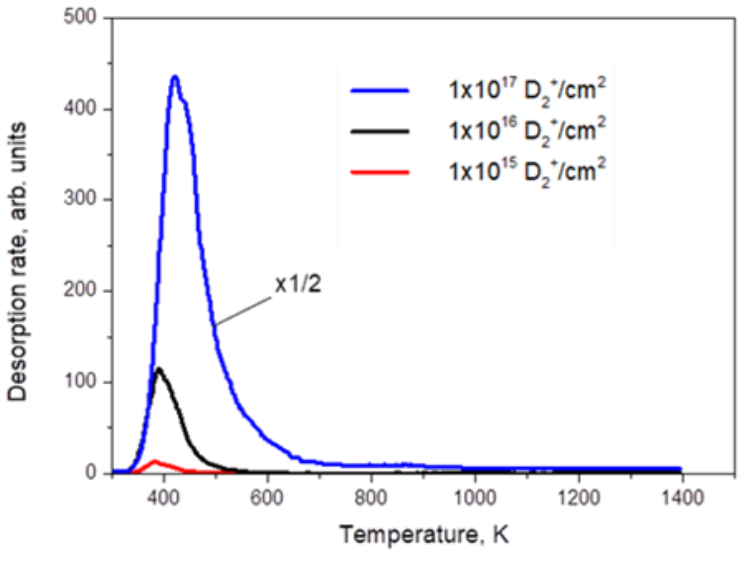

$a$ desorption practically coincides for the both studied steels. A slight difference can be noted for ODS steel, which consists in a better resolution of the first peak by two maxima for a dose of $1 \cdot 10^{16} \mathrm{D}_{2}{ }^{+} / \mathrm{cm}^{2}$ and an insignificant shift of the desorption peak to higher temperatures.

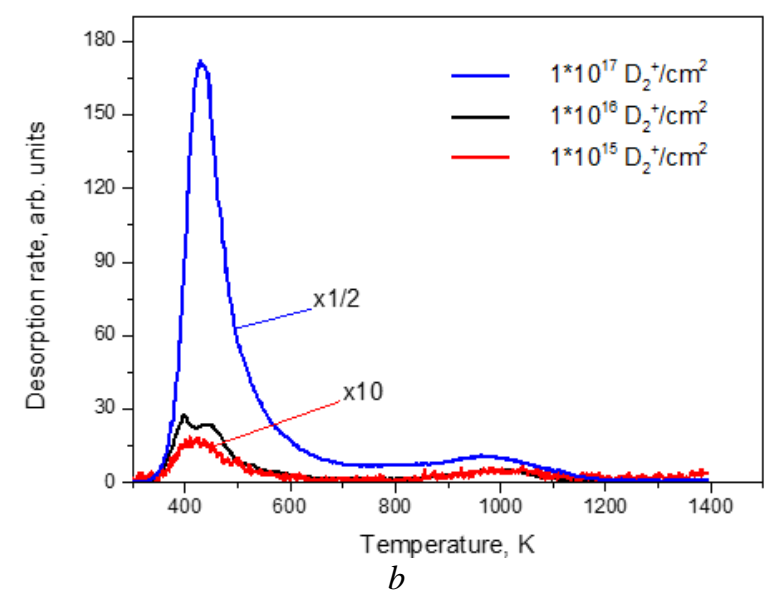

Fig. 2. Deuterium thermal desorption spectra from 18Cr10NiTi (a) and ODS 18Cr10NiTi steels (b) irradiated at $300 \mathrm{~K}$ to $(0.01 \ldots 1.0) \cdot 10^{17} \mathrm{D}_{2}^{+} / \mathrm{cm}^{2}$

Fig. 3 shows TEM examination results for studied steels after implantation with deuterium at room temperature. Analysis of micrographs has shown that at

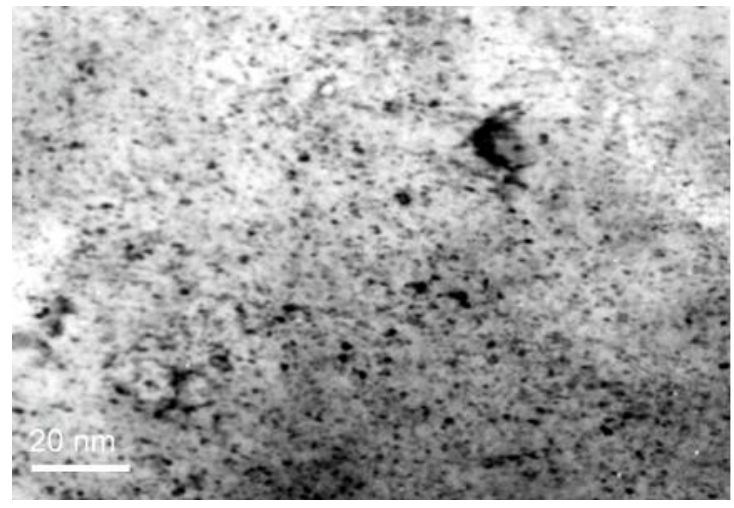

$a$ room temperature only dislocation-type defects were developed (see Fig. 3).

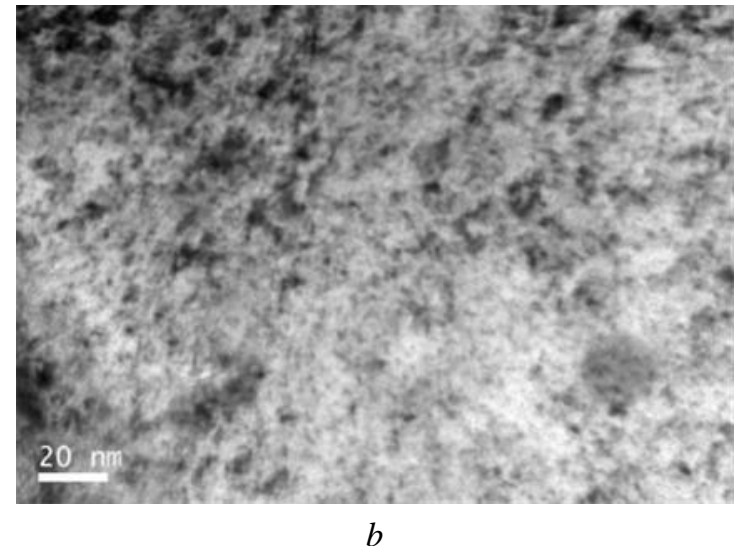

Fig. 3. Microstructure at a depth $0 \ldots 100 \mathrm{~nm}$ from surface of $18 \mathrm{Cr} 10 \mathrm{NiTi}($ a) and ODS $18 \mathrm{Cr} 10 \mathrm{NiTi}(\mathrm{b})$ steels irradiated with deuterium at room temperature to $1 \cdot 10^{17} \mathrm{D}_{2}{ }^{+} / \mathrm{cm}^{2}$

As pointed out earlier the observed deuterium trapping behavior can be successfully simulated by considering the combined influence of the implantation, diffusion, trapping, detrapping, and recombination processes that occur during the experiment [12, 13]. Deuterium trapping in metals is thought to require that deuterium atoms are most likely accompanied with vacancies [14]. However, a comparison of TDS data and microstructural changes in ferritic/martensitic alloys reveal that active desorption of deuterium is strongly correlated with annihilation of dislocation loops, a process which occurs in the same temperature range $[15,16]$. This can imply that most of the deuterium was trapped by dislocation loops. This mechanism of deuterium capture seems possible but probably occurs most strongly at the initial stages of irradiation, since in the fluence range $(1 \ldots 2) \cdot 10^{20} \mathrm{D}_{2} / \mathrm{m}^{2}$ the density of dislocation loops tends to saturate at room temperature, thereby causing a saturation in retention as well [16].

Implantation of deuterium in austenitic stainless steels is accompanied by the creation of dislocation type defects also (see Fig. 3,a). On the other hand, the calculations presented in paper [12] showed that values of deuterium binding energy with various traps suggested that the major deuterium traps are probably radiation-induced interstitial dislocation loops and vacancy type defects that correspond to the two stages of gas release in the desorption spectrum. However, the difference in the observed radiation-induced microstructure of two austenitic steels with and without titanium indicates that the presence of a dislocation defect subsystem probably does not significantly affect the distribution, quantity and temperature range of retention of implanted deuterium. Therefore, it must be 
concluded that for $18 \mathrm{Cr} 10 \mathrm{NiTi}$ steel the thermal desorption in temperature range of $300 \ldots 600 \mathrm{~K}$ were caused by detrapping of deuterium from vacancies and vacancy clusters.

For the ODS $18 \mathrm{Cr} 10 \mathrm{NiTi}$ steel, the thermal desorption spectra of deuterium in the temperature range $300 \ldots 600 \mathrm{~K}$, as well as the systems of dislocation loops ('black spots') that develops after irradiation at $T_{\text {room }}$ have no significant differences (see Fig. 3,b). It can be assumed that the mechanisms responsible for the trapping and release of deuterium from the ODS steel have become the same.

The difference in the behavior of deuterium in the two studied steels is manifested in the presence of the release stage at high temperature $\sim 970 \mathrm{~K}$ for ODS 18Cr10NiTi steel (see Fig. 2,b).

Additional stage in the TDS on the one hand can be explained by the fine grain size and the presence of yttria oxides, which provide strong trapping sites in the steel matrix. Deuterium trapped in oxides has a higher activation energy than deuterium trapped at grain boundaries; therefore, the second peak at high temperature may correspond to hydrogen trapped in dispersed yttria [17]. On the other hand, the introduction of nanocarbides or nanonitrides as hydrogen-trapping sites in steels is often discussed to play a crucial role in hydrogen embrittlement $[18,19]$. Carbides, such as VC, $\mathrm{TiC}$, and $\mathrm{NbC}$, are most often considered as hydrogentrapping sites [20]. The size and coherency of the specific precipitates were crucial in terms of $\mathrm{H}$ trapping ability [19, 21]. It should be noted, that a coherent interface - there is perfect registry of the lattices; coherent with strain - having some strain with the interface, due to imperfect matching; semi-coherent interface - the introduction of dislocations reduces the strain energy (but they themselves contribute to the energy of the system); incoherent - there is no matching of the interface.

In this work, the microstructures of ODS 18Cr10NiTi steel samples implanted with deuterium at room temperature and subsequently annealed to the temperature of the beginning of the second stage of deuterium desorption, namely $800 \mathrm{~K}$, and its midpoint $1000 \mathrm{~K}$ were studied. Fig. 4 shows TEM images of precipitates with sizes of $3 \ldots 10 \mathrm{~nm}$. Electron microprobe analysis had showed that precipitates

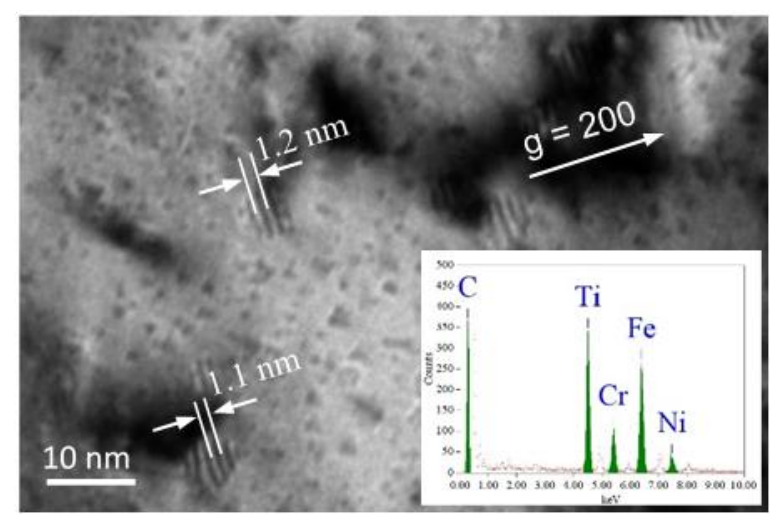

contain mainly titanium, yttrium, zirconium, oxygen and carbon (see inset Fig. 4).

Fig. 4,a shows TEM images of the nanometric coherent precipitates in two beams conditions $(g=200)$. For these precipitates a Moiré contrast are observed and moiré fringes perpendicular to $\mathrm{g}$ with the spacing of moiré fringes $(1.0 \mathrm{~nm}<\mathrm{D}<1.3 \mathrm{~nm})$. These are caused by a little misfit between lattice parameter of the precipitates and the matrix. For moiré fringes perpendicular to $\mathrm{g}$ active diffraction vector, the following equation can be considered $D=d_{1} d_{2} /\left(d_{2}-d_{1}\right)$, where D - spacing of moiré fringes; $d_{1}, d_{2}-$ interplanar spacing of the matrix and the precipitate [22]

Considering measured in this work mean value of $\mathrm{D}=1.1 \mathrm{~nm}$ and $\mathrm{d}_{1}=0.179 \mathrm{~nm}$ with $\mathrm{g}=200$, the calculated value of $\mathrm{d}_{2}=0.214 \mathrm{~nm}$ is close to the reticular distance of $\{200\}$ planes in the TiC precipitates $\left(\mathrm{d}_{200}=0.216 \mathrm{~nm}\right)$. Electron microprobe analysis confirms this nature of precipitates (see inset Fig. 4,a).

Fig. 4,b shows an example of an oxide particles taken under $\mathrm{g}_{220}$. No-contrast lines perpendicular to the g-vector $\left(g_{220}\right.$ and $\left.g_{200}\right)$ can be observed in most of the oxide particles, indicating that they are coherent/semicoherent with the matrix. D spacing in this case is $1.3 \mathrm{~nm}<\mathrm{D}<2.0 \mathrm{~nm}$. Electron microprobe analysis confirms that nature of precipitates is ( $\mathrm{Y}(\mathrm{Zr})$ Ti-O) (see inset Fig. 4,b).

The strains associated with a coherent interface raise the total energy of the system, and for sufficiently large atomic misfit or interfacial area it becomes energetically more favorable to replace the coherent interface with a semicoherent interface in which the disregistry is periodically taken up by misfit dislocations. The spacing between moiré fringes nearly equals that between the interfacial misfit dislocations [23]. It was found experimentally that the inter-spacings between nocontrast lines are different among different $\mathrm{Y}_{2} \mathrm{Ti}_{2} \mathrm{O}_{7}$ particles and vary from about $1.4 \ldots 2.2 \mathrm{~nm}$. The difference between the calculated inter-spacing $(1.4 \mathrm{~nm})$ and that measured from TEM images was explained by the strained lattice planes (change in inter-planar spacings) of $\mathrm{Y}_{2} \mathrm{Ti}_{2} \mathrm{O}_{7}$ particles and the matrix [23]

Several large particles $(>20 \mathrm{~nm}$ ) in Fig. 4,b does not show no-contrast lines, and thus seem to be incoherent with the matrix.

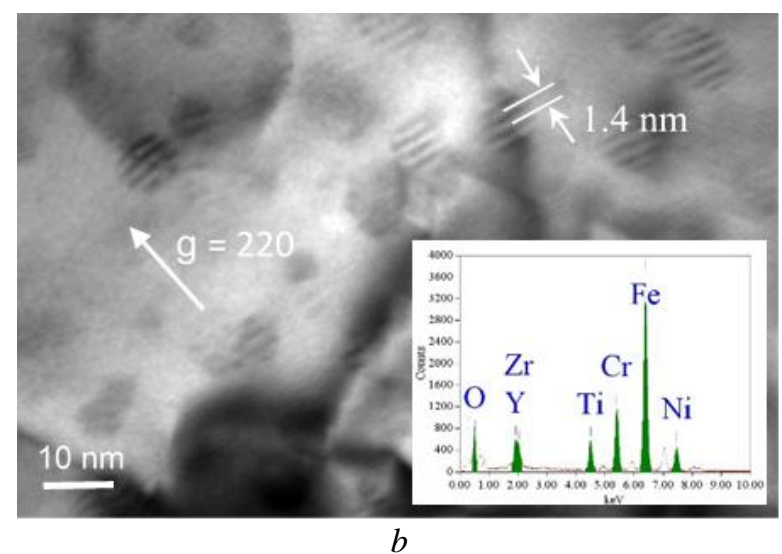

Fig. 4. TEM micrograph of TiC particles taken under $g_{200}(a)$ and $\left(Y(\mathrm{Zr})\right.$-Ti-O) particles taken under $g_{220}(b)$ with multiple no-contrast lines, owing to the small inter-spacing. Moiré fringes of the nanometric precipitates on steel was received in two beams conditions. Electron microprobe analysis of precipitates (inset $a, b$ ) 
Several types of hydrogen traps are currently known including lattice spacings, dislocations, grain boundaries, vacancy clusters, and precipitates. The hydrogen trapping at the inclusions, to some extent, can lower the amount of diffusible hydrogen in the matrix, and consequently improve the resistance to hydrogen embrittlement [24]. However, about the mechanism of hydrogen trapping at the inclusion matrix interface there are conflicting opinions. For example, some studies indicate that the hydrogen trapping at the inclusions is mainly attributed to the elastic interaction of coherency strain with hydrogen atoms, while some other studies show that the misfit dislocations at the interfaces play a dominant role [25].

About the susceptibility of the precipitates of Y-Ti-O and $\mathrm{TiC}$ to hydrogen trapping are known the following. The coherency of $\mathrm{TiC}$ is kept at the interfaces when the inclusion is in the stage of nucleation. The growth of inclusion can lead to the loss of coherency when the inclusion size $(L)$ is larger than a critical value $\left(L_{\mathrm{c}}\right)$. When $L \leq L \mathrm{c}$, the accumulation of hydrogen atoms at the interfaces is attributed to coherency strain. When $L>L c$, the part of coherency losses, the elastic strain induced by lattice misfit decreases and the misfit dislocations are introduced [25]. The accumulation of hydrogen at the interfaces is a combining effect of two stresses respectively induced by lattice misfit and misfit dislocations [19]. The first direct observation of hydrogen trapping sites in $\mathrm{TiC}$ precipitation-hardening steel through atom probe tomography shown that the deuterium atoms were definitely observed on the broad surface of TiC platelets, which indicated that the broad interface between the matrix and $\mathrm{TiC}$ was the main trapping site [20].

As was shown in Ref. [23] shown over 95\% of all $\mathrm{Y}_{2} \mathrm{Ti}_{2} \mathrm{O}_{7}$ particles are semi-coherent with the matrix in austenitic ODS steel. A strong lattice distortion was detected by TEM and XRD analyses. The lattice distortion is anisotropic owing to the different lattice misfits between parallel planes of $\mathrm{Y}_{2} \mathrm{Ti}_{2} \mathrm{O}_{7}$ particles and the austenite matrix.

The hydrogen-trapping property of nano-sized yttria $\left(\mathrm{Y}_{2} \mathrm{O}_{3}\right)$ dispersed $316 \mathrm{~L}$ austenitic steel was studied in [17]. The high-pressure gas-charging method was applied to quantify the effect of yttria oxides $\left(\mathrm{Y}_{2} \mathrm{O}_{3}\right)$ on thermal desorption behavior of hydrogen was used. Hydrogen thermal desorption spectra from 316L ODS steel after exposure to $10 \mathrm{MPa}$ hydrogen at $150{ }^{\circ} \mathrm{C}$ for $120 \mathrm{~h}$ has indicated that the release of hydrogen occurs in the temperature range $420 \ldots 900 \mathrm{~K}$.

The change in the hydrogen-trapping property of the coherent and incoherent $\mathrm{TiC}$ particle in a 0.05C-0.20Ti-2.0Ni steel has been investigated on a quantitative basis by thermal-desorption spectrometry [19]. It is shown that incoherent $\mathrm{TiC}$ particles are not able to trap hydrogen at room temperature through cathodic hydrogen charging, due to their high energy barrier for trapping. TiC precipitate have the broad semicoherent interface when the precipitate is small and was supposedly the trap site of hydrogen on the semicoherent interface during cathodic charging at room temperature. However, as the precipitate grows, it decreases the coherency of the side interface, and the desorption peak that was contributed from the side interface shifts to a higher temperature and coincides with the desorption peak of the incoherent $\mathrm{TiC}$ particle at $\sim 1100 \mathrm{~K}$. Thus, TiC precipitates can be regarded as high-temperature traps for deuterium rather than (Y-Ti-O).

\section{CONCLUSION}

We have examined the thermal desorption spectra of deuterium from 18Cr10NiTi and ODS 18Cr10NiTi steel specimens irradiated with $10 \mathrm{keV} \mathrm{D}_{2}{ }^{+}$ions at $300 \mathrm{~K}$. The influence of radiation damage on microstructure and accumulation of deuterium implanted in steels at room temperature and after annealing have been studied. The main results obtained are as follows:

The thermal desorption spectrum from a $18 \mathrm{Cr} 10 \mathrm{NiTi}$ steel have one major peak with two weakly resolved maxima at temperatures 380 and $430 \mathrm{~K}$ while ODS $18 \mathrm{Cr} 10 \mathrm{NiTi}$ steel exhibits deuterium release over a wide temperature range with two well-defined maxima at $\sim 420$ and $\sim 970 \mathrm{~K}$.

The nanometric precipitates (Y-Ti-O) and $\mathrm{TiC}$ are observed in two beams conditions thanks to Moiré fringes perpendicular to $\mathrm{g}$ that indicates on the semicoherence of precipitates.

The thermal desorption in region $300 \ldots 600 \mathrm{~K}$ were caused detrapping of deuterium from vacancies and vacancy clusters. High-temperature stage of deuterium desorption from ODS $18 \mathrm{Cr} 10 \mathrm{NiTi}$ steel with maximum at $\sim 970 \mathrm{~K}$ is due to deuterium detrapping from $\mathrm{TiC}$ precipitates.

\section{REFERENCES}

1. S.J. Zinkle, G.S. Was. Materials challenges in nuclear energy // Acta Materialia. 2013, v. 61, p. 735738.

2. G.R. Odette, M.J. Alinger, B.D. Wirth. Recent developments in irradiation-resistant steels // Annu. Rev. Mater. Res. 2008, v. 38, p. 471-503.

3. F.A. Garner, E.P. Simonen, B.M. Oliver et al. Retention of hydrogen in fcc metals irradiated at temperatures leading to high densities of bubbles or voids // J. Nucl. Mater. 2006, v. 356, p. 122-134.

4. G.D. Tolstolutskaya, V.V. Ruzhitskij, I.E. Kopanets, S.A. Karpov, V.V. Bryk, V.N. Voyevodin, F.A. Garner. Displacement and helium-induced enhancement of hydrogen and deuterium retention in ion-irradiated $18 \mathrm{Cr} 10 \mathrm{NiTi}$ stainless steel // J. Nucl. Mater. 2006, v. 356, p 135-147.

5. V.N. Voyevodin, S.A. Karpov, I.E. Kopanets, V.V. Ruzhytskyi, G.D. Tolstolutskaya, F.A. Garner. Influence of displacement damage on deuterium and helium retention in austenitic and ferritic-martensitic alloys considered for ADS service // J. Nucl. Mater. 2016, v. 468, p. 274-280.

6. A.N. Velikodnyi, V.N. Voyevodin, M.A. Tiкhоnovsky, et al. Structure and properties of austenitic ODS steel 08Cr18Ni10Ti // Problems of Atomic Science and Technology. 2014, N 4(92), p. 94-102.

7. V.F. Rybalko, V.V. Ruzhitskyi, G.D. Tolstolutskaya, V.I. Bendikov. Plasma interaction with structural materials' surface on charged particle accelerators and on plasma assemblies: Report N Y67256, Kharkov, 1983, p. 195.

8. http://www.srim.org/ 
9. G.D. Tolstolutskaya, V.V. Ruzhytskiy, S.A. Karpov, I.E. Kopanets. Retention and features of deuterium detrapping from radiation-induced damages in steels // Problems of Atomic Science and Technology. 2009, N 4(62), p. 29-41.

10. M. Klinger. More features, more tools, more CrysTBox // Journal of Applied Crystallography. 2017, v. 50, p. 1-9.

11. G.D. Tolstolutskaya, V.V. Ruzhytskyi, V.N. Voyevodin, I.E. Kopanets, S.A. Karpov, A.V. Nikitin. The role of radiation damage on retention and temperature intervals of helium and hydrogen detrapping in structural materials // J. Nucl. Mater. 2013, v. 442, p. S710-S714

12. S.A. Karpov, V.V. Ruzhytskiy, I.M. Neklyudov, V.I. Bendikov, G.D. Tolstolutskaya. Parameters of trapping and thermally activated release of deuterium ion-implanted in steel $18 \mathrm{Cr} 10 \mathrm{NiTi} / /$ Metalofizika $i$ Noveishie Teknologii. 2004, v. 12, p. 1661-1670 (in Russian).

13. S.M. Myers. Trapping and Surface Recombination of Deuterium in Fusion Reactor Metals // IEEE Trans. Nucl. Sci. 1983, v. 30(2), p. 1175-1178.

14. J.K. Norskov, F. Besenbacher, J. Bottiger, et al., Interaction of Hydrogen with Defects in Metals: Interplay between Theory and Experiment // Phys. Rev. Lett. 1982, v. 49, p. 1420-1423.

15. D. Hamaguchi, H. Iwakiri, T. Kawamura, et al. The trapping behavior of deuterium in $\mathrm{F} 82 \mathrm{H}$ ferritic/martensitic steel // J. Nucl. Mater. 2009, v. 386388, p. 375-378.

16. K. Ono, M. Miyamoto, F. Kudo. Release of deuterium from irradiation damage in $\mathrm{Fe}-9 \mathrm{Cr}-2 \mathrm{~W}$ ferritic alloy irradiated with deuterium ions // $\mathrm{J}$. Nucl. Mater. 2014, v. 452, p. 46-50.

17. S-W. Baek, E.J. Song, J.H. Kim, Y-H. Lee, K. Sang Ryu, Sa-W. Kim. Hydrogen susceptibility of nano-sized oxide dispersed austenitic steel for fusion reactor // Fusion Engineering and Design. 2017, v. 121, p. 105-110.

18. W. Kesternich, D. Meertens. Microstructural evolution of a Titanium-stabilized $15 \mathrm{Cr}-15 \mathrm{Ni}$ steel // Acta Metall. 1986, v. 34, p. 1071-1082.

19. F.G. Wei, K. Tsuzaki. Quantitative analysis on hydrogen trapping of TiC particles in steel // Metal Trans A. 2006, v. 37, A (2), p. 331-353.

20. J. Takahashi, K. Kawakami, Y. Kobayashi, T. Tarui. The first direct observationof hydrogen trapping sites in $\mathrm{TiC}$ precipitation-hardening steel through atom probe tomography // Scripta Mater. 2010, v. $63(3)$, p. $261-264$

21. H. Oka, M. Watanabe, N. Hashimoto, et al. Morphology of oxide particles in ODS austenitic stainless steel // J. Nucl. Mater. 2013, v. 442, p. 164168.

22. B. Rouxel1, C. Bisor, Y. De Carlan, A. Courcelle, A. Legris. Influence of the austenitic stainless steel microstructure on the void swelling under ion irradiation // EPJ Nuclear Sci. Technol. 2016, v. 2, N 30, p. 11.

23. X. Mao, K.H. Oh, S.H. Kang, T.K. Kim, J. Janga. On the coherency of $\mathrm{Y}_{2} \mathrm{Ti}_{2} \mathrm{O}_{7}$ particles with austenitic matrix of oxide dispersion strengthened steel // Acta Materialia. 2015, v. 89, p. 141-152.

24. S.A. Karpov, G.D. Tolstolutskaya, V.N. Voyevodin. The most probable mechanisms of material characteristics degradation due to accumulation of hydrogen and predicting the possible scenarios of maintain its resource // Problems of Atomic Science and Technology. Series "Physics of Radiation Effect and Radiation Materials Science”. 2018, N 5(117), p. 3-15.

25. W. Qin and J. A. Szpunar. A general model for hydrogen trapping at the inclusion matrix interface and its relation to crack initiation // Phil. Mag. 2017, v. 97, issue 34, p. 3296-3316.

\section{ВЛИЯНИЕ МИКРОСТРУКТУРЫ АУСТЕНИТНЫХ НЕРЖАВЕЮЩИХ СТАЛЕЙ Х18Н10Т И Х18Н10Т ДУО НА ДЕСОРБЦИЮ ДЕЙТЕРИЯ}

\section{А.С. Кальченко, В.В. Ружицкий, С.А. Карпов, И.В. Колодий, М.А. Тихоновский, Г.Д. Толстолуцкая, А.Н. Великодный и В.Н. Воеводин}

Исследованы спектры термодесорбции дейтерия из образцов сталей Х18Н10T и Х18Н10Т ДУО, облученных ионами 10 кэВ $\mathrm{D}_{2}^{+}$. Изучено влияние радиационных повреждений на микроструктуру и накопление дейтерия после его имплантации в стали при комнатной температуре и после отжига. Спектр термодесорбции из стали Х18Н10Т ДУО демонстрирует выделение дейтерия в широком интервале температур с двумя максимумами при $\sim 420$ и $\sim 970$ К. Рассмотрены два типа преципитатов - оксиды (Y-Ti-O) и карбиды (TiC) для объяснения механизма удержания дейтерия до высоких температур отжига.

\section{ВПЛИВ МІКРОСТРУКТУРИ АУСТЕНІТНИХ НЕРЖАВІЮЧИХ СТАЛЕЙ Х18Н10Т I Х18Н10Т ДЗО НА ДЕСОРБЦЮ ДЕЙТЕРІЮ}

\section{О.С. Кальченко, В.В. Ружицький, С.О. Карпов, І.В. Колодій, М.А. Тихоновський, Г.Д. Толстолуцька, О.М. Великодний і В.М. Воєводін}

Досліджено спектри термодесорбції дейтерію із зразків сталей Х18Н10Т і Х18Н10Т Д3О, опромінених іонами 10 кеВ $\mathrm{D}_{2}^{+}$. Вивчено вплив радіаційних пошкоджень на мікроструктуру і накопичення дейтерію після його імплантації в сталі при кімнатній температурі і після відпалу. Спектр термодесорбції зі сталі X18Н10T ДЗО демонструє виділення дейтерію в широкому інтервалі температур з двома максимумами при $420 \mathrm{i}$ 970 К. Розглянуто два типи преципітатів - оксиди (Y-Ti-O) і карбіди (ТiC) для пояснення механізму утримання дейтерію до високих температур відпалу. 